\title{
PENGGUNAAN PEMASARAN DIGITAL PADA USAHA HOME INDUSTRY KOPI LOMBOK DI DESA SIGERONGAN KABUPATEN LOMBOK BARAT
}

\author{
Lilik Handajani ${ }^{\left.{ }^{*}\right)}$, Akram $^{2}$, Lalu Muhamad Furkan ${ }^{3}$, Ahmad Rifa' ${ }^{4}$ \\ ${ }^{1)}$ Program Studi Magister Akuntansi Fakultas Ekonomi dan Bisnis, \\ Universitas Mataram \\ Jl. Majapahit 62, Mataram 83125, Lombok -Indonesia \\ ${ }^{*}$ Alamat korespondensi : lilikhandajani@unram.ac.id
}

\begin{abstract}
ABSTRAK
Permasalahan mendasar dalam pengembangan usaha mikro, kecil dan menengah (UMKM) adalah berkaitan dengan pemodalan, manajemen usaha, pengelolaan keuangan dan pemasaran produk yang dihasilkan. Sebagian besar UMKM terutama skala usaha mikro pada industri rumahan (home industry) masih mengalami masalah dalam memperoleh dan meningkatkan penjualan secara kontinu karena pemasaran produk yang mengandalkan cara-cara pemasaran konvensional, seperti penjualan melalui pameran, konsinyasi maupun penjualan secara langsung. Dengan manajemen usaha yang dilakukan ini berdampak pada biaya operasional penjualan yang cukup tinggi, perputaran modal menjadi lambat dan terhambatnya proses produksi serta volume penjualan relatif stagnan sehingga menyebabkan peluang dan potensi memperoleh pendapatan dan meraih pangsa pasar menjadi berkurang. Usaha mikro Kopi Lombok merupakan home industry yang berada di Desa Sigerongan Kabupaten Lombok Barat yang mengusung produk unggulan daerah. Kegiatan pengabdian masyarakat kemitraan ini melakukan pendekatan edukasi dan pendampingan pemasaran secara digital sebagai terobosan strategi pemasaran untuk menjual produk kopi Lombok dengan memanfaatkan penggunaan teknologi. Hal ini karena pemasaran tradisional tidak sepenuhnya lagi efektif bagi pasar yang sebagian besar masyarakat sudah beralih ke pemanfaatan teknologi komunikasi. Model pemasaran berbasis digital diharapkan dapat diadopsi oleh pelaku home industry dalam memasarkan produknya sehingga dapat berdampak pada peningkatan pendapatan usaha mikro sehingga sektor UMKM dapat semakin berkembang. Adopsi model pemasaran digital dalam implementasinya menyesuaikan dengan keterpahaman dan kemampuan pengguna dalam pemanfaatannya sehingga hasil akhir diharapkan pelaku usaha mikro Kopi Lombok maupun home industry lainnya dapat mengaplikasikan secara mandiri untuk mendukung pemasaran produk yang dihasilkan.
\end{abstract}

Kata-kata kunci : desa sigerongan, pemasaran digital, kopi lombok, usaha mikro 


\section{PENDAHULUAN}

Usaha mikro kecil dan menengah yang dikenal sebagai UMKM merupakan salah satu bentuk usaha ekonomi rakyat yang banyak dilakukan oleh masyarakat sebagai penggerak perekonomian Indonesia. Sumbangan UMKM terhadap PDB Indonesia mencapai angka 60,34\% pada tahun 2017 yang berarti lebih dari $60 \%$ produk barang dan jasa yang diproduksi di Indonesia berasal dari UMKM (Mubarok, 2018). Diantara UMKM yang ada, usaha mikro merupakan sebagian besar cara untuk memperoleh penghasilan sebagai sumber kehidupan maupun untuk menambah pendapatan dalam rumah tangga. Usaha mikro adalah usaha produktif dengan aset kurang dari 50 juta rupiah dengan omzet maksimal 300 juta rupiah. Sebagian besar usaha mikro juga dilakukan dalam bentuk usaha-usaha rumahan (home industry) yang banyak tersebar dalam masyarakat. Dengan pengelolaan modal dan sumberdaya yang relatif kecil serta pengetahuan dan kemampuan manajerial pengelolaan usaha yang terbatas menyebabkan UKM cenderung memiliki penjualan yang relatif stagnan dan pangsa pasar yang sempit sehingga sulit untuk berkembang.

Masalah riil yang banyak dialami oleh UMKM adalah permodalan, distribusi barang, legalitas perijinan, pembukuan manual dan pemasaran secara online (Islamiyati, 2017). Pemasaran produk saat ini menjadi salah satu faktor krusial dalam pengembangan usaha karena pemasaran bekerja dalam ekosistem Teknologi Informasi yang kompleks dan berkembang sangat dinamis dengan menggabungkan sumberdaya internal dan eksternal yang mensyaratkan interaksi diantara produsen, konsumen, maupun kemitraan pemasaran dan layanan melalui pemanfaatan teknologi (Stone, 2014). Berkaitan dengan kegiatan pemasaran produk/jasa yang dijual usaha mikro, cara pemasaran secara online atau digital masih menjadi tantangan usaha UMKM saat ini untuk berkembang. $\mathrm{Hal}$ ini karena kurangnya pengetahuan dan adaptasi terhadap penggunaan teknologi untuk pengembangan usaha masih relatif lemah. Oleh karena itu dibutuhkan sinergi dari UMKM, akademisi, media dan industri serta dukungan pemerintah sehingga UMKM dapat tumbuh dan berkembang. Upaya ini sejalan dengan visi presiden Jokowi Widodo untuk menjadikan Indonesia sebagai The Digital Energy of Asia pada 2020 dengan nilai transaksi mencapai 130 milyar dolar dapat tercapai (Islamiyati, 2017).

Pada sebagian besar UMKM terutama yang masih dalam skala mikro, model pemasaran untuk menawarkan produk yang dihasilkan 
juga masih konvensional yang mengandalkan penjualan produk secara langsung dengan pertemuan antara pedagang dan pembeli sehingga jumlah penjualan relatif kecil dengan jumlah penjualan yang tidak dapat dipastikan dalam setiap harinya. Penjualan secara titipan (konsinyasi) yang mensyaratkan pembayaran tunai (kas) dilakukan secara barang terjual juga menyebabkan modal mengendap terlalu lama pada produk yang belum terjual. Hal ini akan berdampak pada pendapatan secara ekonomi yang didapatkan oleh pelaku UMKM skala usaha mikro yang juga sangat terbatas. Bahkan kadang-kadang modal menjadi tidak berputar sehingga tidak dapat melakukan produksi lagi karena belum ada penjualan dalam suatu waktu. Oleh karena itu diperlukan suatu upaya untuk meningkatkan penjualan produk pada home industry dengan memanfaatkan kemajuan dan perkembangan teknologi saat ini melalui kegiatan pemasaran produk berbasis digital (digital marketing). Argumentasi sejalan yang mendukung perlunya pemasaran digital dikemukakan oleh Bala dan Verma (2018) yang menyatakan bahwa konsumen akan mencari dan mencari lebih banyak di internet untuk menemukan penawaran terbaik dari penjual dibandingkan dengan metode tradisional atau konvensional. Mendukung temuan sebelumnya, García et. al,. (2019) menyatakan bahwa internet dan pemasaran digital telah berperan dalam menarik perhatian dan mempertahankan pengguna internet sehingga tindakan strategis yang dapat dilakukan adalah memanfaatkan loyalitas pengguna internet untuk pemasaran digital.

Di Desa Sigerongan Kabupaten Lombok Barat beberapa waktu terakhir ini telah berkembang usaha-usaha mikro dalam bentuk home industry dengan hasil produkproduk lokal yang mengangkat keunggulan khas daerah seperti kopi Lombok, penganan opak-opak dan jaje tujak kering. Dari produk-produk yang ada tersebut kopi Lombok cukup memiliki peminat, nama dan nilai jual yang cukup baik diterima oleh konsumen sehingga diperlukan upaya untuk mengangkat citra dan brand kopi Lombok produksi home industry desa Sigerongan menjadi produk yang semakin dikenal oleh masyarakat lokal maupun dikenalkan secara nasional sebagai produk unggulan daerah. Hal ini secara tidak langsung akan dapat meningkatkan pendapatan usaha home industry bagi pelaku usaha mikro.

Salah satu upaya yang dapat dilakukan adalah mengedukasi dan mengenalkan bentuk pemasaran dalam bentuk digital sebagai strategi pendukung bagi pemasaran cara konvensional yang dilakukan selama ini dengan menggunakan digital 
marketing. Pemasaran digital adalah suatu usaha untuk mempromosikan sebuah merk produk dengan menggunakan media elektronik/media digital (Karinovv,

2018) yang berpotensi dapat menjangkau konsumen secara tepat waktu, pribadi, dan relevan. Tujuan utama pemasaran digital adalah menarik pelanggan dan memungkinkan pemasar dan pelanggan berinteraksi melalui pemanfaatan media elektronik oleh pemasar untuk mempromosikan produk atau layanan ke pasar (Yasmin et. al., 2015). Tipe pemasaran digital mencakup banyak teknik dan praktik yang terkandung dalam kategori pemasaran internet, seperti social media marketing, content marketing, branding, web design dan lainnya.

Pemasaran tradisional sudah tak lagi efektif bagi pasar yang sebagian besar masyarakat sudah beralih ke teknologi komunikasi terkini (Yasha, 2018). Seiring dengan kebutuhan masyarakat terhadap informasi, media sosial dapat dimanfaatkan sebagai media pemasaran untukmendukung aktivitas bisnis serta mempermudah dan memperkuat fungsi komunikasi kepada publik (Suryani, 2014). Manfaat pemasaran digital bagi perusahaan dan UKM antara lain adalah dapat terhubung dengan mudah dengan konsumen secara online, konversi penjualan yang lebih tinggi bagi konsumen tertarget, biaya pemasaran yang lebih hemat, dapat melayani konsumen secara real time dan potensi peningkatan pendapatan bagi UKM (Brian, 2019). Dengan bentuk pemasaran digital yang memanfaatkan pengetahuan masyarakat terhadap teknologi diharapkan dapat meningkatkan pangsa pasar penjualan produk menjadi lebih luas. Salah satu indikator meningkatnya kesejahteraan pelaku UMKM adalah dengan meningkatnya omzet penjualan yang salah satu cara untuk mencapainya adalah dengan memaksimalkan strategi pemasaran digital (Hapsoro et. al., 2019). Cara pemasaran produk yang lebih kreatif dengan menggunakan media teknologi diharapkan dapat meningkatkan akses penjualan dan akses perolehan pendapatan yang lebih tinggi bagi pelaku usaha mikro secara umum, dan terutama pada usaha mikro home industry kopi Lombok di desa Sigerongan Kabupaten Lombok Barat.

Kegiatan

pengabdian masyarakat kemitraan pada usaha mikro Kopi Lombok di Desa Sigerongan Lombok Barat ini bertujuan untuk (1) mengidentifikasi permasalahan dan kendala dalam penjualan produk pada usaha mikro home industry Kopi Lombok; (2) mengenalkan dan mengedukasi cara pemasaran produk kopi Lombok melalui pemanfaaatan media 
pemasaran secara digital untuk meningkatkan pangsa pasar dan menjangkau konsumen kopi Lombok secara lebih luas; (3) melakukan pendampingan pada pelaku usaha mikro dalam menggunakan dan memanfaatkan pemasaran digital dan (4) mendorong dan memotivasi pelaku usaha home industry Kopi Lombok untuk secara mandiri mampu menggunakan media pemasaran digital dalam mendukung penjualan produk sehingga dapat meningkatkan pendapatan usaha. Dengan meningkatnya pemahaman dan menumbuhkan kesadaran bagi pelaku usaha home industry tentang pemasaran digital maka omzet penjualan dapat ditingkatkan melalui cara penjualan yang responsif terhadap kebutuhan konsumen. Ke depan pelaku usaha home industry Kopi Lombok dapat menggunakan secara mandiri cara pemasaran digital untuk mendukung penjualan produk sehingga dapat meningkatkan pangsa pasar dan pendapatan bagi pelaku usha mikro sehingga dapat mandiri secara finansial.

\section{METODE KEGIATAN}

Kegiatan pengabdian
masyarakat kemitraan pada usaha
mikro Kopi Lombok di desa
Sigerongan Kabupaten Lombok Barat
ini dilakukan sebagai upaya untuk
membantu pelaku usaha mikro home
industry sehingga dapat
meningkatkan pangsa pasar dan

meningkatkan pendapatan yang diperoleh melalui metode pemasaran yang efektif. Oleh karena itu diperlukan upaya-upaya yang dapat mengatasi permasalahanpermasalahan pada usaha mikro Kopi Lombok sehingga dapat meningkatkan penjualan produk dan meningkatkan pendapatan melalui kegiatan pemasaran produk yang lebih responsif dan agresif terhadap kebutuhan konsumen. Dengan memanfaatkan trend dalam masyarakat yang sudah beralih ke teknologi informasi maka pemasaran secara digital menjadi solusi yang tepat untuk mengatasi permasalahan yang ada. Dengan demikian ke depan pelaku usaha mikro Kopi Lombok dapat meningkatkan pemasaran produk dan dapat mandiri secara ekonomi .

Untuk mengatasi permasalahan-permasalahan yang dihadapi pelaku usaha mikro home industry dalam pemasaran produk secara digital akan dilakukan edukasi dan pendampingan tentang cara penggunaan media pemasaran digital dalam menjual produk yang mereka hasilkan. Kegiatan edukasi dan pendampingan diharapkan dapat menumbuhkan kepercayaan diri pelaku usaha mikro dalam pemanfaatan teknologi informasi untuk memasarkan produk mereka. Pelaku akan dibimbing dalam pembuatan dan penggunaan media pemasaran digital untuk menjual 
produk mereka sehingga melalui kegiatan pendampingan untuk dapat memetakan masalah mendasar yang ada sekaligus merumuskan solusi pemecahannya.

Adapun pendekatan atau metode yang digunakan dalam melaksanakan kegiatan pengabdian masyarakat pada koperasi adalah sebagai berikut:

1. Mengidentifikasi kendala, kesulitan dan permasalahan riil yang dihadapi oleh pelaku usaha mikro dalam mengembangkan usahanya yang selama ini terkendala masalah modal yang tidak berputar yang disebabkan oleh metode pemasaran yang masih menggunakan cara-cara konvensional.

2. Melakukan pendataan masalah melalui wawancara mendalam dengan pelaku usaha mikro home industry baik terkait kendala keuangan, manajemen usaha dan pemasaran produk.

3. Melakukan diskusi interaktif dengan pelaku usaha mikro home industry untuk mencari solusi bersama dengan mengenalkan metode-metode pemasaran modern yang dapat dipahami dengan mudah dan digunakan oleh pelaku usaha mikro home industry untuk meningkatkan pendapatannya.

4. Merancang metode pemasaran yang tepat dan sesuai kebutuhan dan kemampuan pemahaman pelaku usaha home industry sehingga dapat diimplementasikan dengan relatif mudah sesuai dengan kebutuhan dan kemampuan pemahaman pelaku usaha.

5. Melakukan pola edukasi dan pendampingan dalam menerapkan sistem pemasaran berbasis digital sesuai kebutuhan dan kemampuan pemahaman sehingga pelaku usaha mikro home industry dapat secara mandiri mengaplikasikan dalam usahanya.

\section{HASIL DAN PEMBAHASAN}

Berdasarkan hasil kunjungan pada usaha mikro home industry Kopi Lombok, wawancara dan diskusi interaktif dengan pelaku usaha mikro dapat dirumuskan beberapa hal terkait pemanfaatan pemasaran digital pada usaha mikro. Meskipun pelaku usaha mikro telah mengenal media sosial, namun penggunaannya masih sebatas hanya sebagai media pengenalan produk dan belum memanfaatkan sebagai sarana pemasaran produk. Bentuk pemasaran produk Kopi Lombok secara digital (digital marketing) dianggap perlu untuk diperkenalkan kepada pelaku UKM Kopi Lombok agar dapat meningkatkan dan meraih pangsa pasar penjualan dan menjangkau segmen konsumen yang lebih luas dan beragam. Hasil kegiatan pengabdian masyarakat 
kemitraan pemanfaatan pemasaran digital dapat disajikan dalam beberapa bagian sebagai berikut : (1) identifikasi permasalahan dan kendala dalam pemasaran konvensional; (2) introduksi dan penggunaan metode pemasaran digital dalam penjualan produk; (3) perancangan metode pemasaran digital sesuai kebutuhan pelaku usaha mikro dan (4) pendampingan dan edukasi penggunaan pemasaran digital bagi pelaku usaha mikro. Adapun hasil kegiatan secara lengkap disajikan sebagai berikut :

\section{Identifikasi Permasalahan dan Kendala dalam Pemasaran Konvensional.}

Permasalahan yang dihadapi oleh usaha mikro dalam mengembangkan usahanya dengan menggunakan metode pemasaran konvensional. Dari hasil kunjungan, wawancara dan diskusi dengan pelaku usaha mikro dalam memasarkan kopi Lombok secara langsung dapat diidentifikasi beberapa masalah sebagai berikut :

a. Pemasaran produk secara konvensional memerlukan pertemuan antara pembeli dna penjual secara langsung, sehingga segmen konsumen yang dilayani menjadi terbatas dalam lingkup yang sempit.

b. Pemasaran dengan cara menitipkan barang ke suatu toko (metode konsinyasi) akan menyebabkan modal usaha mengendap karena uang hasil penjualan akan diterima jika barang sudah laku terjual.

c. Perputaran penjualan (sales turnover) menjadi lebih lambat jika mengandalkan penjualan secara langsung maupun konsinyasi, sehingga produk mengendap lebih lama yang berisiko mengalami penurunan kualitas terutama bagi produk berupa makanan hasil olahan.

d. Proses produksi seringkali menjadi terhambat karena mengandalkan perputaran modal usaha yang diperoleh dari hasil penjualan yang lambat sehingga menghambar keberlangsungan usaha.

e. Ketika usaha mikro menggunakan modal yang berasal dari pinjaman eksternal (seperti lembaga kredit atau bank) maka akan menghambat ketersediaan dana untuk melakukan angsuran pinjaman sehingga akan mengurangi tingkat .

\section{Introduksi dan Penggunaan Metode Pemasaran Digital dalam Penjualan Produk \\ Pengenalan hal baru kepada pelaku usaha mikro memiliki tantangan untuk dapat diterima, termasuk juga dalam hal pengenalan metode pemasaran baru di luar kebiasaan yang mereka lakukan.


Dalam memberikan metode pemasaran digital juga tidak terlepas dari sikap defensif bahwa metode pemasaran yang mereka lakukan sudah tepat. Oleh karena itu dilakukan pendekatan secara persuasif agar mereka dapat menerima dengan pemanfaatan teknologi dalam pemasaran produk dengan menyampaikan manfaatmanfaat positif yang dapat diperoleh dengan pemasaran digital untuk melengkapi model pemasaran konvensional yang selama ini dilakukan oleh pelaku usaha mikro. Diskusi interaktif dilakukan dengan pelaku usaha mikro home industry untuk mencari solusi bersama dengan mengenalkan metodemetode pemasaran berbasis teknologi yang dapat dipahami dengan mudah dan digunakan oleh pelaku usaha mikro home industry untuk meningkatkan pendapatannya. Berdasarkan hasil diskusi dengan pelaku usaha mikro dapat diidentifikasi manfaat penggunaan yang dapat diperoleh dengan pemasaran digital yang dapat dirumuskan sebagai berikut :

a. Memperluas pangsa pasar penjualan produk dalam wilayah yang lebih luas dengan pemanfaatan order melalui pemanfaatan digital marketing karena penjual dapat terhubung dengan mudah dengan konsumen secara online. b. Meningkatkan jumlah konsumen peminat produk dalam segmen yang lebih luas karena konversi penjualan yang lebih tinggi bagi konsumen tertarget.

c. Dapat melayani konsumen secara real time dan penjualan produk kepada segmen konsumen yang lebih luas.

d. Perputaran modal menjadi lebih cepat dan terencana sehingga dapat mendukung kelancaran proses produksi.

e. Penghematan biaya pemasaran produk

f. Berpotensi dapat mengurangi risiko barang jadi yang mengendap terlalu lama karena belum terjual.

g. Omzet penjualan menjadi meningkat dengan metode pemasaran yang cenderung aktif dengan memanfaatkan pemasaran secara digital.

h. Cara pemasaran produk yang lebih kreatif dengan menggunakan media teknologi diharapkan dapat meningkatkan akses penjualan dan akses perolehan pendapatan yang lebih tinggi bagi usaha mikro home industry kopi Lombok di desa Sigerongan Lombok Barat.

\section{Perancangan Metode Pemasaran Digital Sesuai Kebutuhan Pemasaran Pada Pelaku Usaha Mikro \\ Perancangan metode} pemasaran digital harus disesuaikan 
dengan kebutuhan dan kemampuan yang dimiliki oleh pelaku usaha mikro home industry sehingga dapat diimplementasikan dengan relatif mudah. Pada dasarnya pelaku usaha di era masyarakat digital saat ini telah memiliki mengenal mediamedia sosial meskipun belum banyak yang memanfaatkannya secara optimal dalam pemasaran produk, terutama bagi pelaku usaha home industry Kopi Lombok. Selain tetap menggunakan platform media sosial untuk mengenalkan produk Kopi Lombok, kegiatan pengabdian ini juga merancang website dalam bentuk blogspot untuk melakukan penjualan secara online dan bergabung dalam situs online marketplace.

Platform media sosial seperti instagram Kopi dengan memperkaya konten produk Kopi Lombok dan meng-update deskripsi produk dan pengenalan jenis produk masyarakat publik dan konsumen secara lebih luas. Pemanfaatan website dalam bentuk blogspot Kopi Lombok juga dirancang sebagai media lain untuk mengenalkan produk secara lebih luas dan memungkinkan merespon tanggapan, masukan dan saran sesuai harapan dari konsumen untuk semakin meningkatkan kualitas dan nilai jual dari produk. Upaya untuk melakukan penjualan secara online bagi produk Kopi Lombok juga dilakukan dengan bergabung dalam situs online marketplace. Informasi tentang konten produk direncanakan akan diperbarui secara berkala oleh mitra dengan pendampingan dari tim pengabdian sesuai dengan perkembangan produk yang dijual sehingga dapat memberikan informasi terkini tentang deskripsi, jenis, harga dan ketersediaan produk. Adapun media pemasaran digital Kopi Lombok yang telah dirancang sesuai kebutuhan mitra dapat diakses melalui tautan sebagai berikut https://kopilombokntb.blogspot.com $/ ? \mathrm{~m}=1$. Media. 




Gambar 1 : Platform Media Blogspot untuk Interaksi Pemasaran Dengan Konsumen

Kopi Robusta Lombok asli 100\% kopi robusta Lombok dengan proses tradksional meialui tangan tangan handal puluhan tahun

Tersedia 2 Varian : Original dan Kopi Jahe (menggunakan jahe merah dan putih) (Cisi 150 gram sensasi robusta bagi penikmat kopi.

Hyukngopi

1 komentar

Gambar 2. Pengenalan Konten Produk melalui Media Digital

Adapun media pemasaran digital lainnya agar produk kopi Lombok semakin dikenal oleh masyarakat dan memperluas pangsa konsumen adalah dengan mengoptimalkan media instagram dengan cara mengupdated informasi terbaru terkait konten dan varian produk sebagaimana yang dapat diakses melalui tautan berikut ini : https://instagram.com/mahira.kopi.I ombok?igshid=bxe9qyi57qt3 


\section{(0) | Instagram}

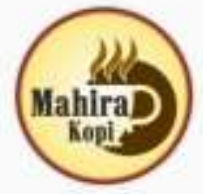

\section{mahira.kopilombok}

50 posts 255 folowers 274 follawing

Mahira Nopi Lombok

1009:flobusta iop Lombok, traditonal roasting strong tastes.ony far spesal persone

Noleholehtumboi

Sigerongan Lingsar, NTE

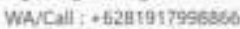

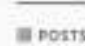

Gambar 2. Media Pemasaran Digital Melalui Instagram

\section{Pendampingan dan Edukasi}

Penggunaan Pemasaran Digital Bagi Pelaku Usaha Mikro

Tujuan dari pendampingan dan edukasi penggunaan pemasaran digital terhadap pelaku usah mikro Kopi Lombok adalah untuk meningkatkan pemahaman dan ketrampilan dalam melakukan pemasaran digital secara mandiri. Edukasi dan pendampingan diperlukan agar pelaku usaha mikro memiliki kesadaran dan termotivasi bahwa penggunaan pemasaran digital diperlukan untuk menunjang pemasaran produk Kopi Lombok agar lebih dikenal oleh masyarakat dan konsumen yang secara tidak langsung dapat meningkatkan akses penjualan produk yang dihasilkan.

Edukasi dan pendampingan dilakukan dalam bentuk tutorial kepada mitra tentang bagaimana mengisi informasi konten produk, deskripsi dan jenis produk serta merespon pesanan dari konsumen.
Melalui upaya tersebut diharapkan mitra dapat secara kontinu belajar dan beradaptasi menggunakan media pemasaran digital dalam penjualan produknya. Dengan demikian pada akhirnya pelaku Home Industry Kopi Lombok mampu secara mandiri dapat mengaplikasikan dalam usahanya sehingga dapat memperluas pangsa pasar produk sehingga dapat meningkatkan pendapatan pada usaha mikro Kopi Lombok.

\section{KESIMPULAN}

1. Permasalahan utama pada usaha mikro terutama berkaitan dengan aspek manajemen usaha, pemodalan, pengelolaan keuangan dan pemasaran produk

2. Masyarakat lebih mengenal dan teredukasi tentang tata cara pemasaran produk kopi Lombok melalui pemanfaaatan media pemasaran secara digital 
3. Masyarakat telah memiliki akun media sosial dan dapat mengoperasikannya dalam rangka memasarkan produk secara digital.

4. Pelaku usaha home industry Kopi Lombok untuk telah secara mandiri mampu menggunakan media pemasaran digital dalam mendukung penjualan produk

\section{UCAPAN TERIMAKASIH}

Terimakasih disampaikan kepada Lembaga Pengabdian Kepada Masyarakat Universitas Mataram, yang telah memberikan dukungan dana untuk melaksanakan kegiatan pengabdian kepada masyarakat melalui Dana Dipa BLU (PNBP) Universitas Mataram tahun Anggaran 2019.

\section{DAFTAR PUSTAKA}

Bala M, Verma D. 2018. A Critical Review of Digital Marketing. International Journal of Management, IT \& Engineering, 8 (10), 321-339.

Brian R. 2019. 10 Manfaat Digital Marketing Bagi Perusahaan dan Bisnis UKM. https://www.maxmanroe.com /manfaat-digitalmarketing.html. Diakses 20 Februari 2019

García JJL, Lizcano D, Ramos CMQ, Matos N. 2019. Digital Marketing Actions That Achieve a Better Attraction and Loyalty of Users: An Analytical Study. Future Internet 11 (130), 1-16.
Hapsoro BB, Palupiningdyah, Slamet A. 2019. Peran Digital Marketing sebagai Upaya Peningkatan Omset Penjualan Bagi Klaster UMKM di Kota Semarang. Abdimas 23 (2), 117-120.

Islamiyati N. 2017. 5 Permasalahan Utama yang Dihadapi Para Pelaku UMKM. https://www.jagoanhosting.co $\mathrm{m} / \mathrm{blog} / 5$-permasalahanutama-yang-dihadapi-parapelaku-umkm/ Diakses 19 Februari 2019

Karinov. 2018. Mengenal Digital Marketing, Pengertian dan Caranya.

https://karinov.co.id/mengenal -apa-itu-digital-marketing.

Diakses 18 Februari 2019

Mubarok I. 2018. 10 Ide UKM Terbaik dan Cara Mudah Mengelolanya.

https://www.niagahoster.co.id/ blog/ide-usaha-kecil-

menengah/ Diakses pada Februari 2019

Yasha. 2018. Digital Marketing: Panduan Lengkap bagi Pemula.

https://www.dewaweb.com/bl og/digital-marketing-lengkap/ diakses 16 Februari 2019

Stone M. 2014. The new (and everevolving) direct and digital marketing ecosystem. Journal of Direct, Data and Digital Marketing Practice, 16 (2), 71-74.

Suryani I. 2014. Pemanfaatan Media Sosial sebagai Media Pemasaran Produk dan Potensi Indonesia dalam Upaya 
Mendukung

ASEAN

Community 2015. (Studi Social

Media Marketing Pada Twitter

Kemenparekraf RI dan

Facebook Disparbud Provinsi

Jawa Barat). Jurnal

Komunikasi, 8 (2), 123-138.

Yasmin A, Tasneem S, Fatema K.

2015. Effectiveness of Digital
Marketing in the Challenging Age: An Empirical Study. International Journal of Management Science and Business Administration, 1 (5), 69-80. 